\title{
EFFECTS OF VINASSE APPLICATION UNDER THE PHYSICAL ATTRIBUTES OF SOIL COVERED WITH SUGARCANE STRAW
}

\section{CICERO DA S. COSTA ${ }^{1}$, ELVIRA M. R. PEDROSA ${ }^{2}$, MARIO M. ROLIM ${ }^{2}$, HUGO R. B. SANTOS $^{3}$, ALUÍZIO T. CORDEIRO NETO ${ }^{3}$}

\begin{abstract}
Areas under vinasse application have been associated to favorable physical conditions for root development, aeration, infiltration and water movement in soil profile. This study aimed to evaluate changes on physical attributes of soil under sugarcane straw after vinasse application in two sugarcane growing areas (Area 1 and Area 2) under mechanized management in the state of Paraíba, Brazil. In each area, the samples were collected in the 0-0.20, 0.20-0.40 and $0.40-0.60 \mathrm{~m}$ layers of the soil, in 36 points, distributed in a $10 \times 10 \mathrm{~m}$ mesh, one day before and 40 days after vinasse application. The data were submitted to multivariate analysis with repeated measures and geostatistics. The vinasse application decreased soil density and increased total porosity in both Areas and increased organic matter in Area 2. In Area 1 occurred pure nugget effect for the fractions of sand, silt and clay, independent of soil layer. In Area 2, this effect was verified mostly at superficial layers, except for the fraction of clay that presented a moderate degree of spatial dependence.
\end{abstract}

KEYWORDS: residue use, Saccharum, geostatistics, soil moisture, soil density.

\section{EFEITOS DA APLICAÇÃO DE VINHAÇA SOB OS ATRIBUTOS FÍSICOS DO SOLO COBERTO COM PALHIÇO DE CANA-DE-AÇÚCAR}

RESUMO: Áreas submetidas à aplicação de vinhaça têm sido associadas às condições físicas favoráveis ao desenvolvimento radicular, aeração, infiltração e movimento de água no perfil do solo. O trabalho teve como objetivo avaliar variações nos atributos físicos de solo após fertirrigação com vinhaça, em duas áreas, denominadas de Área 1 e Área 2, cultivadas com cana-de-açúcar com cobertura de palhiço sob manejo mecanizado na Paraíba, Brasil. Em cada área, as amostras foram coletadas nas camadas de 0-0,20; 0,20-0,40 e 0,40-0,60 m do solo, em 36 pontos, distribuídos em malha de $10 \times 10 \mathrm{~m}$, um dia antes e 40 dias após a aplicação da vinhaça. Os dados foram submetidos a análises multivariadas com medidas repetidas e geoestatística. A adição da vinhaça ao solo promoveu redução da densidade do solo e aumento da porosidade total nas duas Áreas, e aumento da matéria orgânica na Área 2. Na Área 1, ocorreu puro efeito pepita para as frações areia, silte e argila, independentemente da camada de solo. Na Área 2, esse efeito foi verificado, principalmente nas camadas mais superficiais, com exceção da fração argila, que apresentou moderado grau de dependência espacial.

PALAVRAS-CHAVE: aproveitamento de resíduo, Saccharum, geoestatística, umidade do solo, densidade do solo.

\footnotetext{
${ }^{1}$ Doutor em Engenharia Agrícola, Universidade Federal Rural de Pernambuco.

${ }^{2}$ Professor Associado, Departamento de Tecnologia Rural, Universidade Federal Rural de Pernambuco.

${ }^{3}$ Mestre em Engenharia Agrícola, Universidade Federal Rural de Pernambuco.

Recebido pelo Conselho Editorial em: 6-7-2012

Aprovado pelo Conselho Editorial em: 18-10-2012
} 


\section{INTRODUCTION}

The sugarcane (Saccharum spp.) presents itself on the national scene as the main raw material for the production of sugar and ethanol produced at low cost (OLIVEIRA, 2010). However, the intensively mechanized systems of crop management and the large amount of generated waste promote environmental impacts that affect the quality and, in particular, the physical characteristics of the soil.

The use of straw on the soil is one of the main characteristics of the new system of sugarcane production, which can differentiate from the old, the recent management systems, making it a landmark (ROSSETTO et al., 2008). At the harvest of the sugarcane, without burning, a straw coverage of $10-20 \mathrm{t} \mathrm{ha}^{-1}$ year $^{-1}$ of dry material remains on the soil surface, which corresponds to 40$100 \mathrm{~kg} \mathrm{ha}^{-1}$ of nutrients (VITTI et al., 2008). TOMASINI et al. (2010) studying the effect of different harvesting systems, manual and mechanized sugarcane, raw and burnt, under water infiltration on the soil, found that the system of mechanized harvesting, compared to manual harvesting, promoted decrease of $72 \%$ and $83 \%$ in the values of water infiltration on the soil, respectively, for raw and burned sugarcane; while GARBIATE et al. (2011) evaluating different management systems on sugarcane crop (raw and burned sugarcane) under a Distroferric Red Latosol, concluded that the straw from the mechanical harvesting of raw sugarcane reduces the negative effects on the physical quality of soil.

On the other hand, the sugarcane industry has the vinasse as main liquid residue (FRANCO et al. 2008), which is produced in a proportion of 12-13 L per each liter of alcohol from the sugarcane (MARTINELLI \& FILOSO, 2008) SILVA et al. (2007) demonstrated that the application of vinasse can improve the quality of the soil characteristics, including the increase of water retention capacity and improve of physical structure of the soil.

VASCONCELOS et al. (2010), studying a Distrocohesive Yellow Latosol of the coastal plains in the state of Alagoas, in Brazil, confirmed that the vinasse proved itself effective in the development of aggregates, verified by the occurrence of macroaggregates. In a Latosol cultivated with sugarcane after applications of $1,200 \mathrm{~m}^{3} \mathrm{ha}^{-1}$ of vinasse, on the contrary, ANDRIOLI (1986) found that there was no change in density, total porosity, macro or micro porosity of the soil, due to the fact that do not occur increase of soil organic matter. However, ZOLIN et al. (2011) reported increased organic matter content, soil density and total porosity and, consequently, improve on the physical condition of the soil due to application of vinasse over the years.

The recognition of the importance of the spatial dependence of the physical, chemical and biological soil and the use of geostatistical tools are multiplying the number of studies related to the theme in different crops, including sugarcane (BERNER et al., 2007, GOMES et al., 2008). ROQUE et al. (2008) affirmed that the geostatistical analysis may indicate management alternatives that reduce the effects of spatial variability on crop production, but also to estimate plant responses to certain practices adopted. The aim of this study was to evaluate temporal and spatial variations in physical attributes of the soil irrigated with vinasse in two areas cultivated with sugarcane with straw coverage and mechanized management in the state of Paraíba, Brazil.

\section{MATERIAL AND METHODS}

The study was conducted in two areas, represented by lots 170 and 124 of the Várzea Cercada farm, Giasa Factory, located in Pedras de Fogo city, state of Paraíba (PB), Brazil, both areas formed by the same type of soil (Argisol). In each area were demarcated 36 collection points, forming a mesh of $10 \times 10 \mathrm{~m}$ between points (Fig.1), totaling 2,500 $\mathrm{m}^{2}(50 \times 50 \mathrm{~m})$. Lot 170 (Area 1), latitude $07^{\circ} 21^{\prime} 29^{\prime \prime} \mathrm{S}$ and longitude $35^{\circ} 00^{\prime} 34^{\prime \prime} \mathrm{W}$, distant from the factory about $3 \mathrm{~km}$, cultivated with the variety SP79-1011 for the 2nd year, and lot 124 (Área 2), latitude 07 20' 45" S and longitude $34^{\circ} 59^{\prime} 22^{\prime \prime} \mathrm{W}$, cultivated with the variety RB855536, 7th year, $5 \mathrm{~km}$ distant. The choice of areas was made according to the soil type, predominant in the region, and management used. 


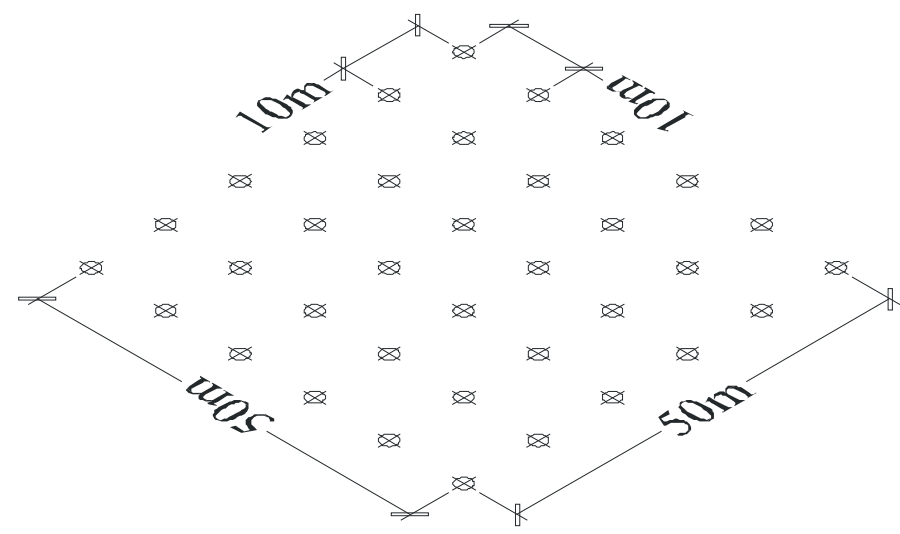

FIGURE 1. Representation of the sampling points in the mesh.

The crop management system was mechanized, from planting to harvest. The harvest performed a week before the beginning of the experiment, provided considerable vegetation coverage on the soil, from the straw of crushed sugarcane. The collection of soil samples were carried out in the period of February-March 2011. The first collection was made one day before the application of vinasse and the second 40 days after. The vinasse is being applied in these areas for 20 years, with an average dosage of $600 \mathrm{~m}^{3} \mathrm{ha}^{-1}$ year-1, conducted via aspersion with the use of hydraulic cylinder.

Soil samples were collected with the assistance of an auger type undeformed sample and a digger, in the layers $0-0.20,0.20-0.40$ and $0.40-0.60 \mathrm{~m}$ during two periods (before and after application of vinasse), totaling 216 soil samples by area. After the collection, the samples were placed in plastic bags and transported to the Laboratory of Soil Mechanics and Utilization of Waste of the Federal Rural University of Pernambuco - UFRPE, for physical analysis.

Initially, the soil samples were air dried, dragged and sieved in $2 \mathrm{~mm}$ mesh, according to the methodology described by EMBRAPA (1997). The soil density (Ds) was determined by the volumetric ring method; the particle density (Dp), by the method of volumetric flask; and the granulometry by the densimeter method of Bouyoucos. The total porosity $(\mathrm{Pt})$ was calculated by the expression: $\mathrm{Pt}=1-(\mathrm{Ds} / \mathrm{Dp})$. The determination of soil moisture $(\Theta \mathrm{v})$ was performed by the gravimetric method in a stove at $105^{\circ} \mathrm{C}$.

For the statistical analysis of temporal variations, the data were analyzed by repeated measures over time, and the means were compared by Tukey test at 5\% probability, using the SAS program - Statistical Analitical System (SAS, 2009). It was also applied descriptive statistics (mean, standard deviation, standard error of the mean, minimum, maximum and coefficient of variation) and verified adherence data to the Normal distribution, according to Kolgomorov-Smirnov test. The discrepant data were eliminated based on the criterion of HOAGLIN et al. (1983). For the analysis of spatial variability, it was used geostatistical tool Geo-EAS (ENGLUND \& SPARKS, 1991). After obtaining the experimental semivariograms, it was performed an adjusted the data to a theoretical model tested (exponential, Gaussian and spherical). The degree of spatial dependence was assessed using the classification proposed by CAMBARDELLA et al. (1994), based on the relation between the nugget effect and the level of adjusted semivariograms.

The values inferior to $25 \%$ characterize strong spatial dependence, between $25 \%$ and $75 \%$ moderate spatial dependence, and above $75 \%$ weak spatial dependence. Function parameters of semivariance adjusted to the theoretical models were used in the construction of maps of the properties studied by the kriging process, in order to define areas of similar variability and divide the area by sub-homogeneous regions. For preparation of contour maps it was used the software Surfer 8.0. 


\section{RESULTS AND DISCUSSION}

The texture of the soil profiles of the studied areas showed uniformity until the depth of $0.60 \mathrm{~m}$ (Table 1). This uniformity is most evident in Area 1, highlighting the percentage of sand, which was approximately 95\% in the three layers. In Area 2, the soil also showed a large amount of sand along the evaluated $0.60 \mathrm{~m}$, however, besides this soil presenting a clay percentage slightly larger than in the previous; its lowest layer $(0.40$ to $0,60 \mathrm{~m})$ was classified as sandy loam, unlike the upper layers that have been classified as sand.

TABLE 1. Physical characterization of the soil for the experimental areas in the Giasa factory, state of Paraíba, Brazil.

\begin{tabular}{|c|c|c|c|c|c|c|c|}
\hline Layer & Ds & $\mathrm{Pt}$ & $\theta v$ & sand & silt & clay & Texture \\
\hline $\mathrm{m}$ & $\mathrm{kg} \mathrm{dm}^{-3}$ & $-\%$ & & \multicolumn{3}{|c|}{$\mathrm{g} \mathrm{kg}^{-1}$} & \\
\hline \multicolumn{8}{|c|}{ Area 1} \\
\hline $0-0.20$ & 1.56 & 41.05 & 13.12 & 948.27 & 24.42 & 27.31 & sand \\
\hline $0.20-0.40$ & 1.61 & 38.95 & 9.02 & 952.18 & 24.21 & 23.61 & sand \\
\hline $0.40-0.60$ & 1.59 & 39.86 & 7.94 & 956.73 & 20.52 & 22.75 & sand \\
\hline \multicolumn{8}{|c|}{ Area 2} \\
\hline $0-0.20$ & 1.51 & 42.66 & 18.98 & 897.17 & 47.03 & 55.80 & sand \\
\hline $0.20-0.40$ & 1.62 & 39.10 & 15.59 & 894.44 & 27.33 & 78.23 & sand \\
\hline $0.40-0.60$ & 1.62 & 38.79 & 15.87 & 861.85 & 25.11 & 113.04 & sandy loam \\
\hline
\end{tabular}

Ds: soil density; Pt: total porosity; $\Theta v$ : volumetric unity.

Assessing the values of $\Theta v$, Ds, Pt and organic matter, depending on the time of application of vinasse for each study area (Table 2), it was verify that only $\Theta v$ was not influenced by the application of vinasse on soil covered with straw. These results differ from those found by PERES et al. (2010), who found that, in the $0-0.20 \mathrm{~m}$ layer, the presence of sugarcane straw in the soil surface reduced water losses almost to half of that observed in bare soil condition. CARVALHO et al. (2011), evaluating the physical properties of three classes of soil cultivated with sugarcane in mechanized harvesting system, concluded that the straw found on the surface resulted in an increase in organic matter content, in formation, aggregation and stability of pores, decreasing the total porosity and consequently increasing the density of soil, particularly in the depth of $0.20-0.40 \mathrm{bm}$.

PERES et al. (2010) found that the influence of the sugarcane straw coverage on $\Theta v$ decreased with increasing depth of soil, of the order of $0.116 \%$ per day, with straw, and $0.159 \%$ per day, without straw, when compared with the 0-0.20m layer. A similar effect was found in this study, when moisture was analyzed as a function of depth (Table 3). However, the authors affirm that the water losses occurred predominantly by deep percolation. Therefore, this factor may have been the main responsible for the reduction of moisture over time, favored by the high prevalence of sand fraction in the soil layers of both areas.

Also for Area 1, the vinasse to the soil promoted an increase of Pt as a result of the reduction of Ds. MIRANDA et al. (2012) observed a significant decrease of the Ds and increasing Pt 10 days after application of vinasse in a soil with 93\% sand. CAMILOTTI et al. (2006) concluded that the soil physical properties were not altered by the application of vinasse, even after the completion of four successive annual applications. ZOLIN et al. (2011) observed that the area that received vinasse application for 12 years had the highest density in the superficial layer of the soil, compared with areas receiving waste for shorter periods (one, two and four years), showing some degree of compactness of that area.

For Area 2, unlike Area 1, only the organic matter did not differ depending on the application of vinasse (Table 2). For Ds and Pt, the behavior was similar to that shown in Area 1. 
In general, there was an interaction between time and depth to $\Theta v$, Ds and Pt, regardless of the studied area. Before the application of vinasse, the $\Theta v$ values decreased with increasing depth, however, after application, the $\Theta v$ values did not differ as a function of depth due to the significant decrease occurred in the first two layers after the residue application (Table 3). The Ds values decreased significantly after the application of vinasse in all layers of the soil (Table 3). However, the $0-0.20 \mathrm{~m}$ layer showed the lowest values differing from the other which did not differ. These results are similar to those reported by MIRANDA et al. (2012), who found no significant difference in Ds in the layer from 0 to $0.50 \mathrm{~m}$ in a sandy soil after 10 days of application of vinasse. Influenced by the decrease in the density of the soil after application of vinasse, the values of $\mathrm{Pt}$ increased significantly at all depths, after residue application, though, in both periods, they remained significantly higher on the most superficial layer of $0-0.20 \mathrm{~m}$ (Table 3).

TABLE 2. Effect of application of vinasse on moisture, soil density, total porosity and organic matter depending on time, in soil covered by sugarcane straw.

\begin{tabular}{rrrrrrrrr}
\hline \multirow{2}{*}{ Area } & \multicolumn{2}{c}{$\begin{array}{c}\text { Volumetric unity } \\
(\%)\end{array}$} & \multicolumn{2}{c}{$\begin{array}{c}\text { Soil density } \\
\left(\mathrm{g} \mathrm{cm}^{-3}\right)\end{array}$} & \multicolumn{2}{c}{$\begin{array}{c}\text { Total porosity } \\
(\%)\end{array}$} & \multicolumn{2}{c}{$\begin{array}{c}\text { Organic matter } \\
\left(\mathrm{g} \mathrm{kg}^{-1}\right)\end{array}$} \\
\cline { 2 - 9 } & \multicolumn{1}{c}{ Before } & After & Before & After & Before & After & Before & After \\
\hline 1 & $10.03 \mathrm{~A}$ & $8.16 \mathrm{~A}$ & $1.58 \mathrm{~A}$ & $1.47 \mathrm{~B}$ & $39.52 \mathrm{~B}$ & $44.50 \mathrm{~A}$ & $1.30 \mathrm{~B}$ & $1.56 \mathrm{~A}$ \\
2 & $16.82 \mathrm{~A}$ & $12.59 \mathrm{~B}$ & $1.58 \mathrm{~A}$ & $1.52 \mathrm{~B}$ & $40.18 \mathrm{~B}$ & $42.16 \mathrm{~A}$ & $1.18 \mathrm{~A}$ & $1.14 \mathrm{~A}$ \\
\hline
\end{tabular}

*Averages followed by the same letters, in the line, do not differ by the Tukey test at $5 \%$ of probability.

TABLE 3. Effect of the vinasse application on the soil covered by sugarcane straw, on the values of volumetric moisture, soil density and total porosity, depending on time and depth.

\begin{tabular}{rlrllll}
\hline \multirow{2}{*}{ Layer $(\mathrm{cm})$} & \multicolumn{2}{c}{$\begin{array}{c}\text { Volumetric moisture } \\
(\%)\end{array}$} & \multicolumn{2}{c}{$\begin{array}{c}\text { Soil density } \\
\left(\mathrm{g} \mathrm{cm}^{-3}\right)\end{array}$} & \multicolumn{2}{c}{$\begin{array}{c}\text { Total porosity } \\
\text { (\%) }\end{array}$} \\
\cline { 2 - 7 } & \multicolumn{1}{c}{ Before } & \multicolumn{1}{c}{ After } & Before & After & Before & After \\
\hline $0-20$ & $16.05 \mathrm{Aa}$ & $10.13 \mathrm{Ba}$ & $1.53 \mathrm{Ab}$ & $1.44 \mathrm{Bb}$ & $41.86 \mathrm{Ba}$ & $45.50 \mathrm{Aa}$ \\
$20-40$ & $12.31 \mathrm{Ab}$ & $9.90 \mathrm{Ba}$ & $1.62 \mathrm{Aa}$ & $1.55 \mathrm{Ba}$ & $39.02 \mathrm{Bb}$ & $41.60 \mathrm{Ab}$ \\
$40-60$ & $11.91 \mathrm{Ab}$ & $11.04 \mathrm{Aa}$ & $1.60 \mathrm{Aa}$ & $1.51 \mathrm{Ba}$ & $39.32 \mathrm{Bb}$ & $42.89 \mathrm{Ab}$ \\
\hline
\end{tabular}

*Averages followed by the same capital letters, in the line, and small letters, in the column, do not differ by the Tukey test at $5 \%$ of probability.

According to the criteria proposed by WARRICK \& NIELSEN (1980), the CV values of the present study were low for the granulometric fractions of sand (2.36) and silt (4.99), while for the clay fraction (12.98 and 16.03) it was observed average CV values (Table 4).

CAMPOS et al. (2007), in an attempt to characterize the spatial variability of physical and hydric attributes of a Hydromorphic Carbic Spodosol in the Zona da Mata in the state of Pernambuco, Brazil, also found low CV values for the fractions of sand (3.12), silt (10.24) and clay (11.73), differentiating the present study only in the clay fraction. Moreover, SOUZA et al. (2008), examining the spatial dependence of the granulometric fractions of an alluvial soil under agricultural cultivation in an irrigated alluvial lot, found mean values of $\mathrm{CV}$ for granulometric fractions of sand $(26,08)$, silt $(16.01)$ and clay $(14,81)$. SILVA et al. $(2010)$, working with the same soil type, also observed average CV values for the three granulometric fractions.

The semivariograms model that best fitted the variables sand, silt and clay is the spherical (Table 4). According to MCBRATNEY \& WEBSTER (1986), the spherical model is one of the most frequent in the adjustment to the semivariograms of soil attributes. However, this result differs from that found by SOUZA et al. (2008), who obtained the Gaussian model with the best fit to the semivariograms of the three granulometric fractions.

It was verified a nugget effect for sand, silt and clay in Area 1, regardless of the soil layer. This may have occurred because of the large uniform area with respect to texture of soil, which is composed of $95 \%$ sand fraction along the three evaluated layers. Thus, is evidenced random 
distribution of data for the three granulometric fractions in Area 1, regardless of depth, proving by observing the semivariograms in Figure 3.

TABLE 4. Descriptive statistics for physical attributes of the soil and parameters of the semivariograms adjusted to the experimental data in Area 2.

\begin{tabular}{lcccc}
\hline \multirow{2}{*}{ Descriptive statistic } & Sand & Silt & \multicolumn{2}{c}{ Clay } \\
\cline { 2 - 5 } & $0.40-0.60 \mathrm{~m}$ & $0.40-60 \mathrm{~m}$ & $0.20-0.40 \mathrm{~m}$ & $0.40-0.60 \mathrm{~m}$ \\
\hline Mean & 86.19 & 2.51 & 8.36 & 11.30 \\
Standard Deviation & 2.03 & 0.75 & 1.09 & 1.81 \\
Median & 86.48 & 2.50 & 8.16 & 11.02 \\
CV (\%) & 2.36 & 4.99 & 12.98 & 16.03 \\
Asymmetry & -0.12 & -0.26 & 0.43 & 0.20 \\
Kurtosis & -0.09 & -0.55 & -0.67 & -0.20 \\
Superior quartile & 84.84 & 2.00 & 7.66 & 10.09 \\
Inferior quartile & 87.52 & 3.00 & 8.77 & 12.88 \\
Total amplitude & 2.68 & 1.00 & 1.11 & 2.79 \\
\hline & & Semivariograms adjustment parameters \\
\hline Nugget Effect (Co) & 2.76 & 0.45 & 0.90 & 2.66 \\
Platform (Co + C1) & 3.85 & 0.60 & 1.26 & 3.17 \\
Reach & 15.07 & 18.60 & 15.78 & 18.20 \\
Co/(Co + C1) & 71.77 & 74.96 & 71.87 & 83.96 \\
Model & Spherical & Spherical & Spherical & Spherical \\
\hline
\end{tabular}

$\mathrm{Co} / \mathrm{Co}+\mathrm{C} 1-$ spatial dependence degree of Cambardella (\%); CV - coefficient of variation. *The values presented on the table above are related only to the sets of data in which was observed spatial dependence degree.

For Area 2, the nugget effect was evident mainly in the superficial layers (Fig. 4), with the exception of the clay fraction which showed a moderate degree of spatial dependence, according to the classification proposed by CAMBARDELLA et al. (1994), in the layer of 0.20 to $0.40 \mathrm{~m}$. The deeper layer (0.40-0.60m) demonstrated a moderate degree of spatial dependence for sand and silt fraction and low-grade to clay. CAMPOS et al. (2007) also found moderate degree of spatial dependence for the three granulometric fractions of soil and diverge from SOUZA et al. (2008) that found a strong degree of dependence for these same variables. Instead, SILVA et al. (2010) observed weak spatial dependence for sand, silt and clay, regardless of depth study.

In this study was found ranges of values of 15.07, 18.60 and 18.20 for sand, silt and clay respectively in the $0.40-0.60 \mathrm{~m}$ layer. Similar results were found by VIEIRA (1997) who obtained ranges of $15 \mathrm{~m}$ to clay and silt in a Dystrophic Purple Latosol under conventional prepare. However, the range of values obtained by SOUZA et al. (2008) and SILVA et al. (2010) for sand, clay and silt in a Fluvic Neosol diverged substantially and showed marked differences between the most superficial layer $(0-0.20 \mathrm{~m})$ and the most deeper $(0.20-0.40$ and $0.40-0.60 \mathrm{~m})$, possibly deriving from the different physical characteristics of each soil, although they were the same type of soil.

The models parameters of the adjusted semivariograms were used to estimate values at unsampled locations by kriging, generating the contour maps (Fig. 2), in which is demonstrated a similarity in the pattern of spatial distribution among the granulometric fractions of the soil. According to LIMA et al. (2006), the closed lines characterize the area with greater variability, while the presence of spaced lines it is a condition of a reduced variability 

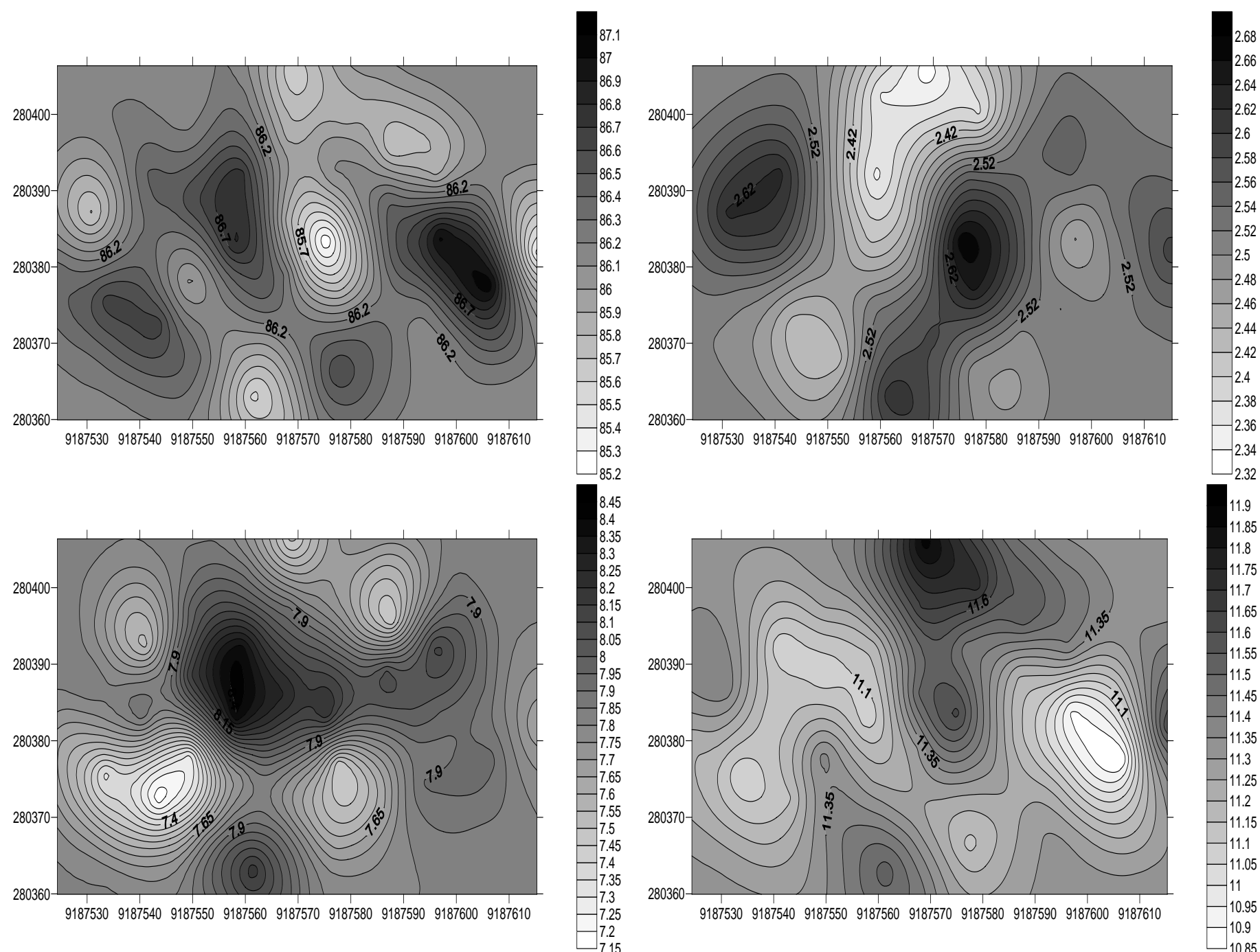

FIGURE 2. Contour maps to sand $(0.40-0.60 \mathrm{~m})(\mathrm{A})$, silt $(0.40-0.60 \mathrm{~m})(\mathrm{B})$, clay $(0.20-0.40 \mathrm{~m})(\mathrm{C})$, and clay (0.40-0.60m) (D), in Area 2, after 40 days of vinasse application.
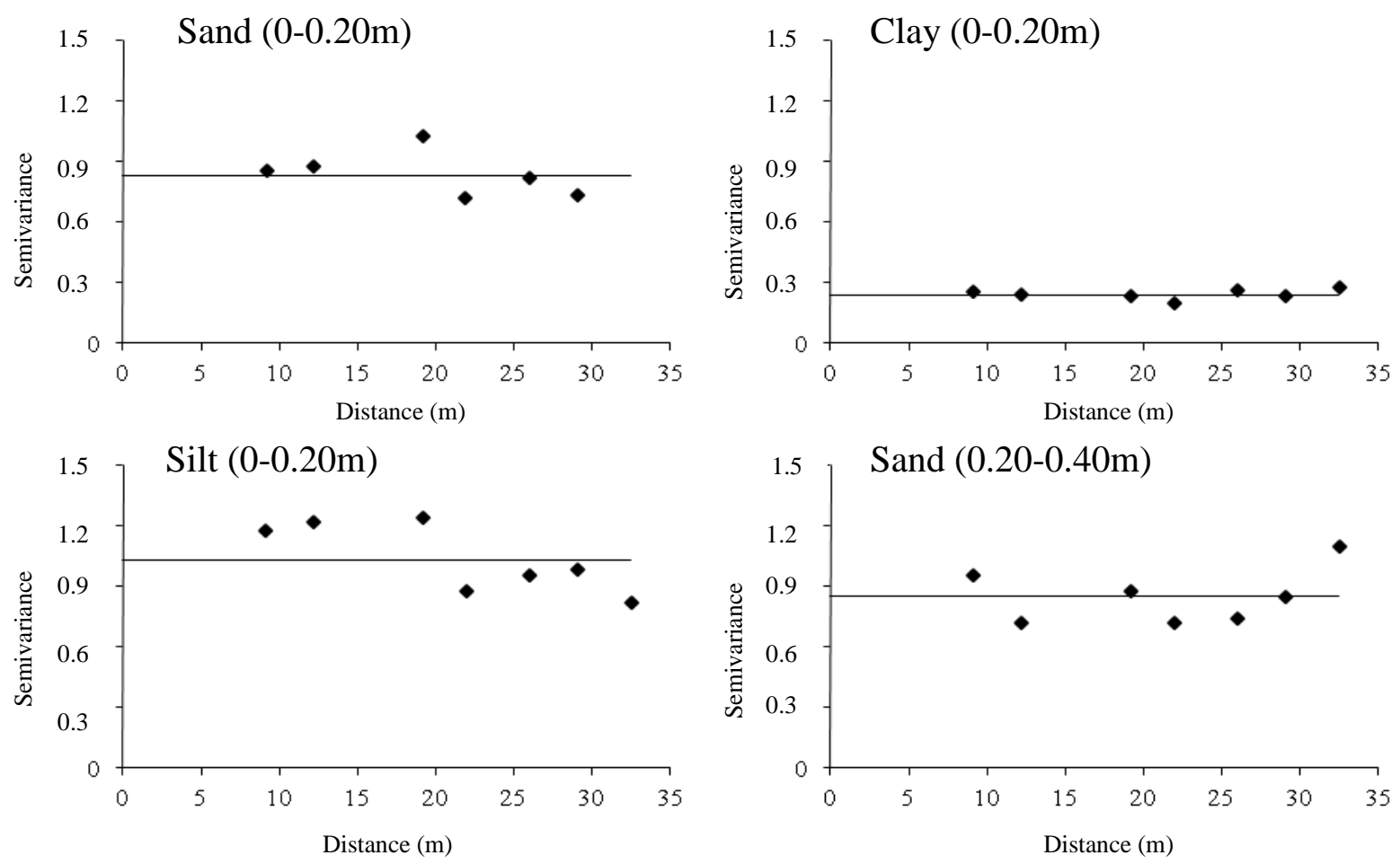

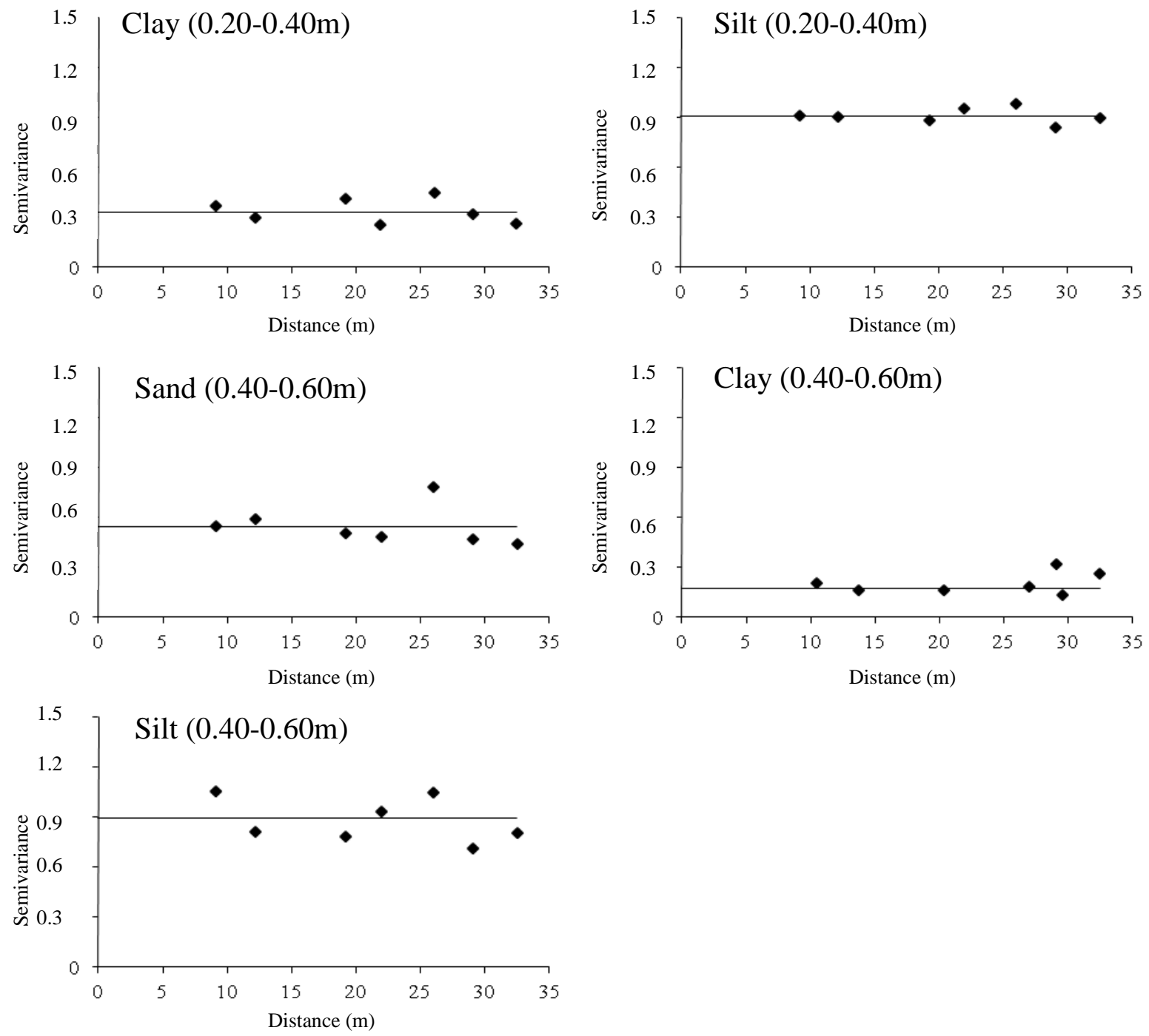

FIGURE 3. Experimental and theoretical semivariograms for sand, clay and silt in the layers 0-0.20, 0.20-0.40 and 0.40-0.60m, in Area 1.
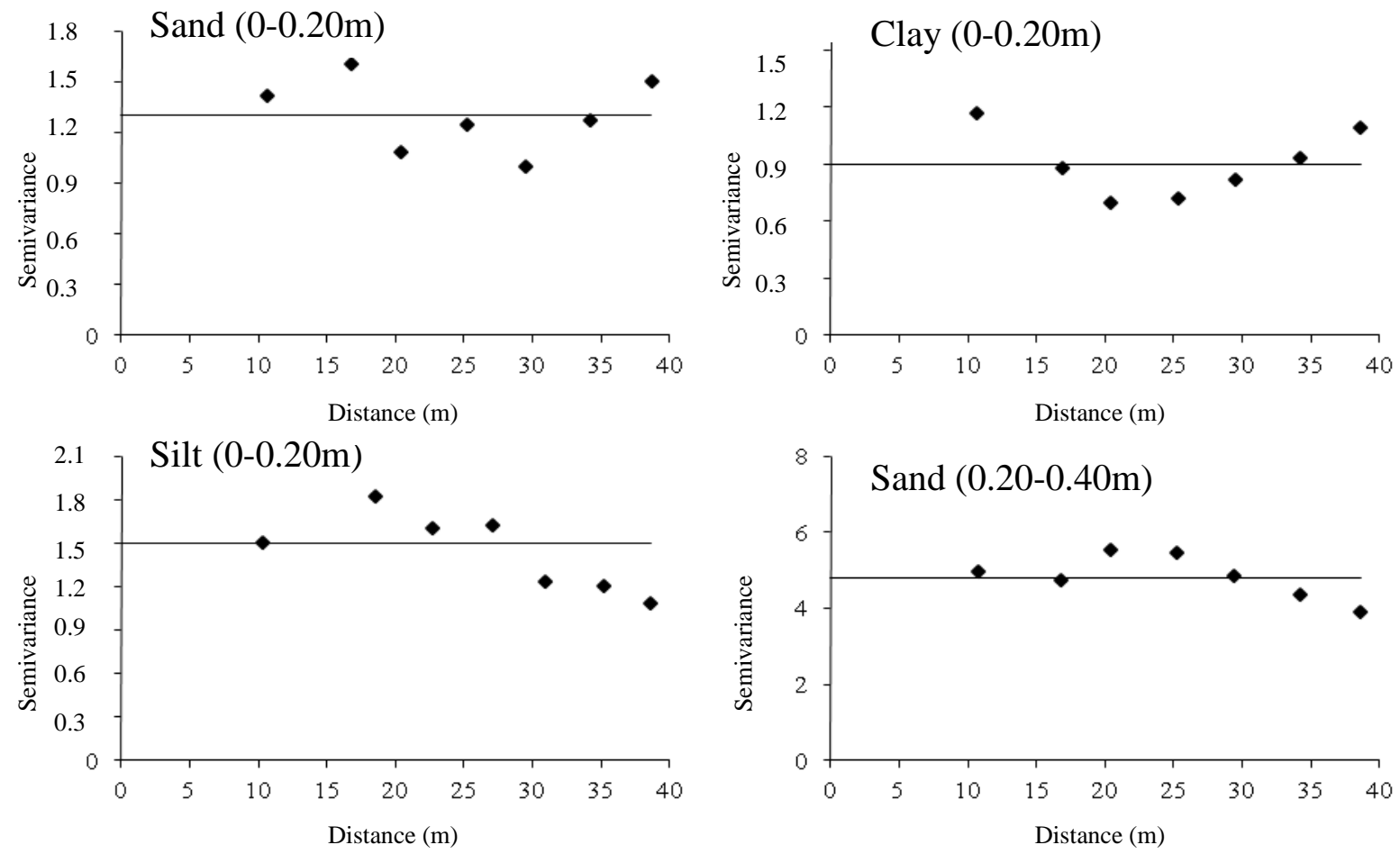

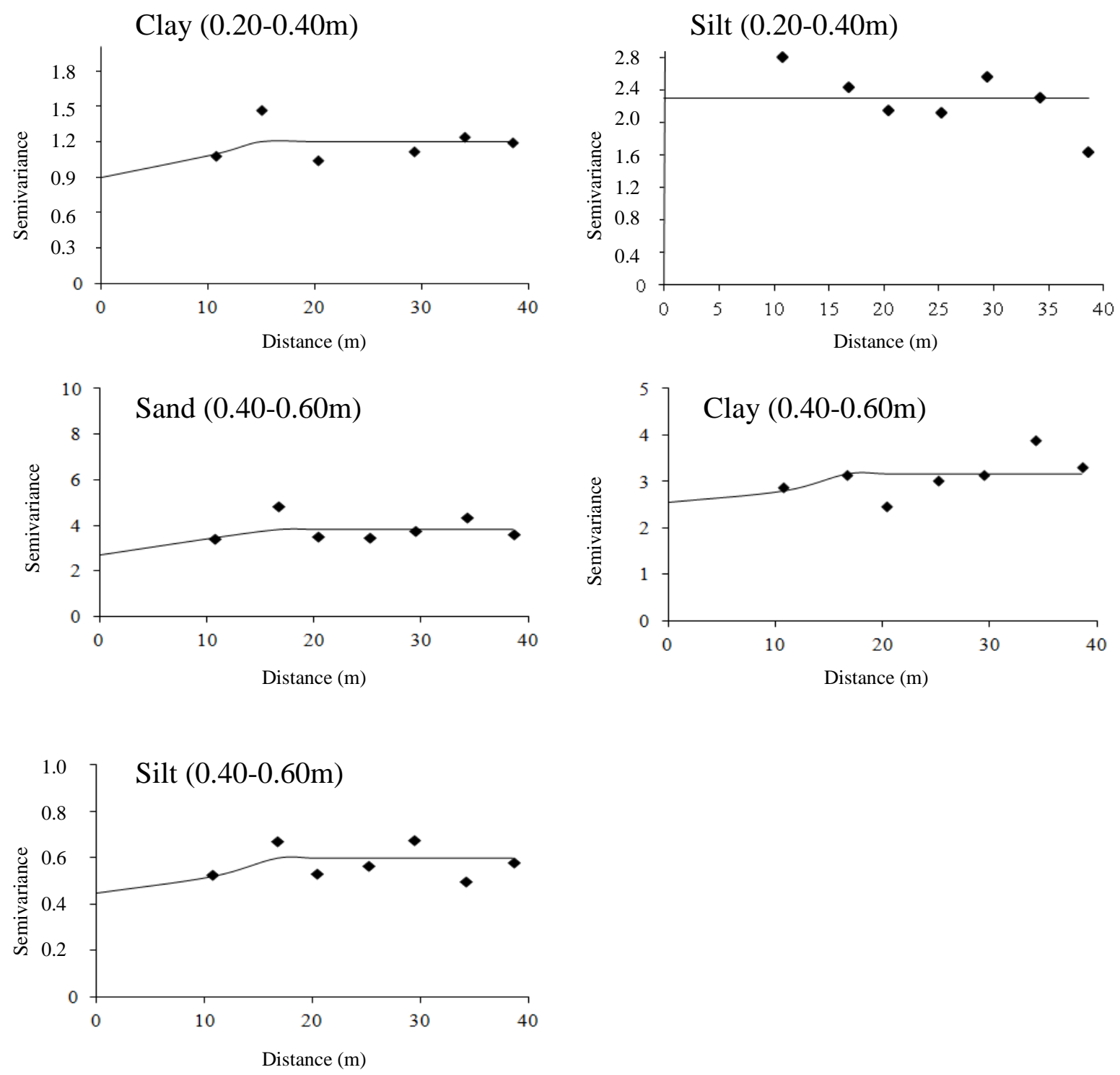

FIGURE 4. Experimental and theoretical semivariograms for sand, clay and silt in the layers 0-0.20, $0.20-0.40$ and $0.40-0.60 \mathrm{~m}$, in Area 2.

\section{CONCLUSIONS}

The period of 40 days after application of vinasse on soil covered by sugarcane straw was sufficient to cause decrease and increase, in soil density and total porosity, respectively, in the two studied areas.

When evidenced the presence of spatial dependence, that ranged from moderate to low degree of dependence.

\section{REFERENCES}

ANDRIOLI, I. Efeitos da vinhaça em algumas propriedades químicas e físicas de um Latossolo Vermelho-Escuro textura média. 1986. 85 f. Tese (Doutorado em Solos e Nutrição de Plantas) Escola Superior de Agricultura "Luiz de Queiroz", Universidade de São Paulo, Piracicaba, 1986.

BERNER, P.G.M.; VIEIRA, S.R.; LIMA, E.; ANJOS, L.H.C. Variabilidade espacial de propriedades físicas e químicas de um Cambissolo sob dois sistemas de manejo de cana-de-açúcar. Revista Brasileira de Ciência do Solo, Viçosa-MG, v.31, n.5, 837-844, 2007. 
CAMBARDELLA, C.A.; MOORMAN, T.B.; NOVAK, J. M.; PAKIN, T.B.; KARLEM, D.L.; TURCO, R.F.; KONOPA, A.A. Field scale variability of soil properties in Central Iowa soils. Soil Science Society of America Journal, Madison, v.58, n.5, p.1501-1511, 1994.

CAMILOTTI, F.; ANDRIOLI, I.; MARQUES, M.O.; SILVA, A.R..; TASSO JÚNIOR, L.C.; NOBILE, F.O. Atributos físicos de um Latossolo cultivado com cana-de-açúcar após aplicações de lodo de esgoto e vinhaça. Engenharia Agrícola, Jaboticabal, v.26, n.3, p.738-747, 2006.

CAMPOS, M.C.C.; FERRAZ, F.B.; FREITAS, E.W.S.; SOUZA, Z.M. Dependência espacial de atributos físicos e hídricos de um Espodossolo da Zona da Mata de Pernambuco. Revista de Biologia e Ciências da Terra, Campina Grande, v.7, n.1, p.84-91, 2007.

CARVALHO, L.A.; MEURER, I.; SILVA JUNIOR, C.A.; CAVALIERE, K.M.V.; SANTOS, C.F.B. Dependência espacial dos atributos físicos de três classes de solos cultivados com cana-deaçúcar sob colheita mecanizada. Revista Brasileira de Engenharia Agrícola e Ambiental, Campina Grande, v.15, n.9, p.940-949, 2011.

EMBRAPA. Manual de métodos de análise de solo. 2 ed. Rio de Janeiro: Centro Nacional de Pesquisa de Solos, 1997. 212p.

FRANCO, A.; MARQUES, M.O.; MELO, W.J. Sugarcane grown in an Oxisol amended with sewage sludge and vinasse: nitrogen contents in soil and plant. Scientia Agricola, Piracicaba, v.65, n.4, p.408-414, 2008.

ENGLUND, E.; SPARKS, A. GeoEAS Geostatistical Environmental Assessment Software. Las Vegas: U.S. Environmental Protection Agency, 1991. (EPA/600/4- 88/033a).

GARBIATE, M.V.; VITORINO, A.C.T.; TOMASINI, B.A.; BERGAMIN, A.C.; PANACHUKI, E. Erosão em entre sulcos em área cultivada com cana crua e queimada sob colheita manual e mecanizada. Revista Brasileira de Ciência do Solo, Viçosa-MG, v.35, n.6, p.2145-2155, 2011.

GOMES, J.B.V.; BOLFE, E.L.; CURI, N.; FONTES, H.R.; BARRETO, A.C.; VIANA, R.D. Variabilidade espacial de atributos de solos em unidades de manejo em área piloto de produção integrada de coco. Revista Brasileira de Ciência do Solo, Viçosa-MG, v.32, n.1, p.2471-2482, 2008.

HOAGLIN, D.C.; MOSTELLER, F.; TYKEY, J.W. Análise exploratória de datos: técnicas robustas, un guia. Lisboa: Salamandra, 1983. 446p.

LIMA, J.A.G.; MENDES, A.M.S.; DUDA, G.P.; FERREIRA, C.V. Variabilidade espacial de características físico-hídricas de um Cambissolo cultivado com mamão no semi-árido do RN. Revista Caatinga, Mossoró, v.19, n.2, p.192-199, 2006.

MCBRATNEY, A.B.; WEBSTER, R. Choosing functions for semi-variograms of soil properties and fitting them to sampling estimates. Soil Science, Oxford, v.37, n.3, p.617-639, 1986.

MIRANDA, T.L.; PEDROSA, E.M.R.; SILVA, E.F.F.; ROLIM, M.M. Alterações físicas e biológicas em solo cultivado com cana-de-açúcar após colheita e aplicação de vinhaça, Revista Brasileira de Ciências Agrarias, Recife, v.7, n.1 p.150-158, 2012.

OLIVEIRA, B.G. Vinhaça da cana-de-açúcar: fluxos de gases de efeito estufa e comunidades de archaea presente no sedimento do canal de distribuição. 2010. 96f. Dissertação (Mestrado em Ciências) - Escola Superior de Agricultura “Luiz de Queiroz”, Universidade Estadual Paulista, Piracicaba, SP, 2010.

PERES, J.G.; SOUZA, C.F.; LAVORENTI, N.A. Avaliação dos efeitos da cobertura de palha de cana-de-açúcar na umidade e na perda de água do solo. Engenharia Agrícola, Jaboticabal, v.30, n.5, p.875-886, 2010. 
ROQUE, M.W.; MATSURA, E.E.; SOUZA, Z.M.; BIZARI, D.R.; SOUZA, A.L. Correlação linear e espacial entre a resistência do solo ao penetrômetro e a produtividade do feijoeiro irrigado.

Revista Brasileira de Ciência do Solo, Viçosa-MG, v.32, n.5, p.1827-1835, 2008.

ROSSETTO, R.; DIAS, F.L.F.; VITTI, A.C.; CANTARELLA, H.; LANDEL, M.G.A. Manejo conservacionista e reciclagem de nutrientes em cana-de-açúcar tendo em vista a colheita mecânica. Informações Agronômicas, Piracicaba, n.124, p. 8-13, 2008. Encarte.

SAS - Institute. SAS/STAT 9.3 users guide. Cary, NC: SAS Institute, 2009.

SILVA, J.J.N.; MONTENEGRO, A.A.A.; SILVA, E.F.F.; FONTES JÚNIOR, R.V.P.; SILVA, A.P.N. Variabilidade espacial de parâmetros de crescimento da mamoneira e de atributos físicoquímicos em Neossolo. Revista Brasileira de Engenharia Agrícola Ambiental, Campina Grande, v.14, p.921-931, 2010.

SILVA, M.A.S.; GRIEBELER, N.P.; BORGES L.C. Uso de vinhaça e impactos nas propriedades do solo e lençol freático. Revista Brasileira Engenharia Agrícola Ambiental, Campina Grande, v.11, n.1, p.45-52, 2007.

SOUZA, E.R.; MONTENEGRO, A.A.A.; MONTENEGRO, S.M.G.L.; SANTOS, T.E.M.; ANDRADE, T.S.; PEDROSA, E.R. Variabilidade espacial das frações granulométricas e da salinidade em um Neossolo Flúvico do semi-árido. Ciência Rural, Santa Maria, v.38, n.2, p.698704, 2008.

TOMASINI, B.A.; VITORINO, A.C.T.; GARBIATE, M.V.; SOUZA, C.M.A.; SOBRINHO, T.A. Infiltração de água no solo em áreas cultivadas com cana-de-açúcar sob diferentes sistemas de colheita e modelos de ajustes de equações de infiltração. Engenharia Agricola, Jaboticabal, v.30, n.6, p.1060-1070, 2010.

MARTINELLI, L.A.; FILLOSO, S. Expansion of sugarcane ethanol production in Brazil: environmental and social challenges. Ecological Applications, Tempe, v.18, n.4, p.885-898, 2008.

VASCONCELOS, R.F.B.; CANTALICE, J.R.B.; OLIVEIRA, V.S.; COSTA, Y.D.J.; CAVALCANTE, D.M. Estabilidade de agregados de um Latossolo Amarelo distrocoeso de tabuleiro costeiro sob diferentes aportes de resíduos orgânicos da cana-de-açúcar. Revista Brasileira de Ciência do Solo, Viçosa-MG, v.34, n.2, p.309-316, 2010.

VIEIRA, S.R. Variabilidade espacial de argila, silte e atributos químicos em uma parcela experimental de um Latossolo Roxo de Campinas (SP). Bragantia, Campinas, v.56, n.1, p.1-17, 1997.

VITTI, A.C.; TRIVELIN, P.C.O.; CANTARELLA, H.; FRANCO, H.C.J.; FARONI, C.E.; OTTO, R. TRIVELIN, M.O.; TOVAJAR, J.G. Mineralização da palhada e crescimento de raízes de canade-açúcar relacionados com a adubação nitrogenada de plantio. Revista Brasileira de Ciência do Solo, Viçosa-MG, v.29, n.32, p.2757-2762, 2008.

WARRICK, A.W.; NIELSEN, D.R. Spatial variability of soil physical properties in the field. In: Hillel, D. Application of soils physics. New York: Academic Press, 1980. p.319-344.

ZOLIN, C.A.; PAULINO, J.; BERTONHA, A.; FREITAS, P.S.L.; FOLEGATTI, M.V. Estudo exploratório do uso da vinhaça ao longo do tempo. I. Características do solo. Revista Brasileira de Engenharia Agrícola e Ambiental, Campina Grande, v.15, n.1, p.22-28, 2011. 